materials, dimensions and cost are referred to, and finally inspection, testing and records are dealt with.

More information is needed on the behaviour of large currents of lightning magnitude when earth electrodes of rod and strip in various combinations are used, with various simple soils such as chalk, clay, loam and sand. The influence of bends upon sideflashing when similar currents are discharged through a down conductor is not known exactly, and much more reliable data are required. Another sphere of uncertainty is whether to isolate a lightning protective system or to bond it to the metallic sheaths of other services. The ability of electric conduit to carry a share of the lightning discharge current (as might be the case if bonding were carried out in a very tall building such as a lighthouse) is doubtful, and much more data are needed. The statistical data available from the Meteorological Office on the prevalence of lightning over the major portion of the world will be very valuable, and if the larger British and Overseas fire insurance companies could be induced to provide separate statistics for lightning claims, later recommendations for protection against lightning would be increasingly trustworthy.

\section{Changes in Mortality-Rates in the United States}

Harold F. Dorn, of the United States Public Health Services, states (Public Health Rep., Dec. 4, 1942) that between 1930 and 1940 the expectation of life at birth of the total population of the United States increased from 59 to 63.3 years, an increase of $4 \cdot 3$ years, or 7 per cent. At the beginning of the century, the expectation of life at birth was $49 \cdot 2$ years as compared with 63.3 years in 1939 , an increase of $14 \cdot 1$ years or 29 per cent. The relative increase in life expectancy was nearly twice as great for non-whites as for whites. The largest relative decreases occurred in the death-rates of children and young adults, but significant decreases took place throughout life even among the older persons. With the exception of deaths from heart disease, cancer and diabetes, the mortality from each of the important causes of death was lower in 1939 than in 1930. For the first time in the history of the registration area, the maternal mortality-rate declined uninterruptedly throughout the entire decade, the relative decrease being 48 per cent among white mothers and $: 4$ per cent among negro mothers.

\section{Chinese Students for Britain}

Tes Chinese students, the first to visit Britain under a new scheme operated by the British Council, are now on their way to Great Britain. They have been given scholarships by the Council, and will study some branch of engineering and will work at the university or college most suited to their special qualifications. Their training is expected to be of special value both because it will equip them for reconstruction work in China, and because their familiarity with British engineering practice and equipment will furnish a link between Great Britain and China.

The names of these students, with their qualifications, are as follow: Shen Yuan (B.Sc. in aeronautical engineering, National Tsing Hwa University, 1940 ; assistant, National. Southwest Associated University, $1940-42$; to study aeronautical engineering). Tsao Pung Hyi (B.Sc. in chemistry, National Tsing Hwa University; research student, Research Department of Agriculture, National Tising
Hwa University, 1938-39; assistant, Chemistry Department, National Tsing Hwa University, 1939 42 ; at Li-Tien Chemical Works, 1942-43 ; to study chemical engineering). Yuan Sui Shan (B.Sc. in civil engineering, National Tsing Hwa University, 1938 ; assistant, Civil Engineering Department, National Southwest Associated University, 1938-41 ; associate engineer, Bureau of Transportation Administration, 1941-42; to study shipbuilding). Meng Ching Yuen (B.Sc. in electrical engineering, National Chiao Tun University, 1938 ; apprentice, Electrical Administra. tion, Kwangsi, 1939 ; technician, Ministry of Communications, 1939-40 ; assistant engineer, Central Electrical Works, 1940-42; to study electrical engineering). Lyn Wei Tze (B.Sc. in mechanical engineering, National Tsing Hwa University, 1940 ; technician, Fifth Army, 1938-39 ; assistant, National Southwest Associated University, 1940-42 ; to study mechanical engineering). Chen Ju Chuan (B.Sc. in chemical engineering, National Chekiang University, 1937 ; associate engineer, Yunnan Tin Works, National Resources Commission, 1937-39 ; assistant, Chemistry Department, National Southwest Associated University, 1940-42 ; to study textile engineering). Lao Ti Li (B.Sc. in chemistry, National Tsing Hwa University, 1940; chemistry assistant, National Central University, 1940-41; chemistry assistant, National Tsing Hwa University, 1942; tu study pharmacy). Chang Tse Shuan (bachelor of law, National Tsing Hwa University, 1940 ; assistant, Economics Department, National Tsing Hwa University, 1940-42; to study planning economics). Fang Pin (B.Sc. in metallurgy, National Yunnan University, 1941 ; apprentice, Kun-hwa Iron and Coal Works, 1939-40 ; associate engineer, Yunnan Metal Works, Ministry of Economic Affairs, 1941-42 ; engineer, Metal Works of Western Yunnan, Ministry of Economic Affairs, 1941-42; to study metallurgy). Prof. Tseou Heou Feo (doctor of science, University of Paris ; formerly professor of chemical engineering, National Chekiang University; dean of College of Science, National Szechuan University).

\section{Announcements}

THE Minister of Agriculture has appointed Prof. E. J. Salisbury, F.R.S., Quain professor of botany in University College, London, to be director 'of the Royal Botanic Gardens, Kew, as from September 1.

The Abbif Henri Breuil has been elected an honorary Fellow of the Royal Society of South Africa.

Dr. Isaiah Bowman, president of the Johns Hopkins University, previously director of the American Geographical Society, has been elected president of the American Association for the Advancement of Science to succeed Dr. Arthur $\mathbf{H}$. Compton, of the University of Chicago. Due to the postponement of the New York meeting Dr. Bowman was elected by postal ballot.

THE following have been elected officers of the Illuminating Engineering Society for the forthcoming session : President: Dr. H. Buckley; Vice-Presidents : Mr. E. Stroud, Dr. W. M. Hampton and Mr. H. C. Weston; Hon. Treasurer: Mr. N. V. Everton; Hon. Secretary : Mr. J. S. Dow ; Members of Council. : H. E. Chasteney, E. E. J. Drake, F. S. Ette, J. G. Holmes, W. C. Huston, H. Lingard, J. F. Stanley, J. W. Whitaker and T. Wilkie. 